

\section{Hydrogen Resource Assessment Hydrogen Potential from Coal, Natural Gas, Nuclear, and Hydro Power}

Anelia Milbrandt and Margaret Mann

Prepared under Task No. H278.2100

Technical Report NREL/TP-560-42773

February 2009

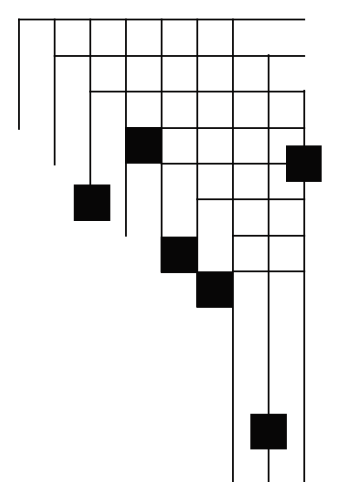




\section{NOTICE}

This report was prepared as an account of work sponsored by an agency of the United States government. Neither the United States government nor any agency thereof, nor any of their employees, makes any warranty, express or implied, or assumes any legal liability or responsibility for the accuracy, completeness, or usefulness of any information, apparatus, product, or process disclosed, or represents that its use would not infringe privately owned rights. Reference herein to any specific commercial product, process, or service by trade name, trademark, manufacturer, or otherwise does not necessarily constitute or imply its endorsement, recommendation, or favoring by the United States government or any agency thereof. The views and opinions of authors expressed herein do not necessarily state or reflect those of the United States government or any agency thereof.

Available electronically at http://www.osti.gov/bridge

Available for a processing fee to U.S. Department of Energy and its contractors, in paper, from:

U.S. Department of Energy

Office of Scientific and Technical Information

P.O. Box 62

Oak Ridge, TN 37831-0062

phone: 865.576 .8401

fax: 865.576 .5728

email: mailto:reports@adonis.osti.gov

Available for sale to the public, in paper, from:

U.S. Department of Commerce

National Technical Information Service

5285 Port Royal Road

Springfield, VA 22161

phone: 800.553.6847

fax: 703.605.6900

email: orders@ntis.fedworld.gov

online ordering: http://www.ntis.gov/ordering.htm 


\section{Acknowledgments}

The study was performed by analysts at the U.S. Department of Energy's (DOE) National Renewable Energy Laboratory (NREL). The authors would like to thank Johanna Levene from NREL and Stephen Lasher from TIAX LCC for their review and recommendations. The authors also extend a special thanks to Fred Joseck from DOE's Hydrogen Program for his continued assistance, making the completion of this study possible. 


\section{List of Acronyms}

$\begin{array}{ll}\mathrm{CH}_{4} & \text { Methane } \\ \mathrm{CO}_{2} & \text { Carbon dioxide } \\ \text { EIA } & \text { Energy Information Administration } \\ \text { GIS } & \text { Geographic Information System } \\ \mathrm{H} 2 \mathrm{~A} & \text { U.S. Department of Energy's Hydrogen Analysis Group } \\ \mathrm{kg} & \text { Kilogram } \\ \mathrm{SMR} & \text { Steam methane reforming } \\ \text { Tonne } & \text { Metric ton } \\ \text { USGS } & \text { U.S. Geological Survey }\end{array}$

\section{Conversions}

Hydrogen from coal: $7.6 \mathrm{~kg}$ of coal $/ \mathrm{kg}$ hydrogen

Hydrogen from natural gas: 4.5 normal cubic meters $/ \mathrm{kg}$ of hydrogen

Hydrogen from nuclear and hydro power: $58.8 \mathrm{kWh} / \mathrm{kg}$ of hydrogen

On average, about 3 gallons of water are needed to produce $1 \mathrm{~kg}$ of hydrogen

$1 \mathrm{~kg}$ of hydrogen can potentially displace $4.35 \mathrm{~kg}$ or 1.58 gallons of gasoline 


\section{Executive Summary}

As an energy carrier, hydrogen can be produced from any primary energy source. Currently, most hydrogen is produced from natural gas via steam reforming. Other sources like coal and biomass can also be used to generate hydrogen through gasification. Electricity, once produced from nuclear, hydro, solar, wind, or geothermal, can generate hydrogen through electrolysis. Given that this wide diversity of energy resources is geographically specific, it's important to understand where resources are located so that appropriate plans can be made for hydrogen production technologies and infrastructure.

The objective of this study is to estimate the hydrogen production potential from coal, natural gas, nuclear, and hydro power by county in the United States, and to create maps for easy visualization of the results. To accomplish this, fossil fuels production and power generation data are analyzed both statistically and graphically using a state-of-the-art Geographic Information System (GIS), a computer-based information system used to create, manipulate, analyze, and visualize geographic information. In addition to estimating the hydrogen potential from the sources mentioned above, the study discussed the major factors that need to be considered when choosing a site for a hydrogen production facility. These include the availability of feedstock, distribution infrastructure, and water. The study concluded that regions with high hydrogen potential, such as the Rocky Mountain States, have access to existing distribution infrastructure, but may not have sufficient water availability.

Previous work by the authors (Milbrandt and Mann 2007) estimated the hydrogen production potential from key renewable resources (wind, solar, and biomass) in the United States at about 1,000 million tonnes per year (far more than would be needed to fuel all cars in the United States), and identified the Great Plains as the region with the highest potential. The present study is a continuation of that work in an attempt to provide a comprehensive picture of all resources currently available for hydrogen production in the country.

The study estimated that more than 72 million tonnes of hydrogen can be produced from coal and natural gas resources, nuclear, and hydro power per year (considering only $30 \%$ of their total current annual production). Leading states include Wyoming (26\% of total potential), Texas (16\%), West Virginia (8\%), Kentucky (6\%), and New Mexico (5\%). The United States consumed about 396 million tonnes of gasoline in 2007 (IEA 2008), therefore the amount of hydrogen derived from these sources could displace about $80 \%$ of this consumption ${ }^{1}$. Although this study uses current production of coal/natural gas and electricity generation from nuclear/hydro power plants rather than the total amount of resources available or power generation capacity, it helps highlight opportunities for first-generation hydrogen production during the transition period to a hydrogen economy.

\footnotetext{
${ }^{1} 1 \mathrm{~kg}$ of hydrogen can potentially displace $4.35 \mathrm{~kg}$ or 1.58 gallons of gasoline.
} 


\section{Table of Contents}

List of Figures........................................................................................................................................... viii

List of Tables ....................................................................................................................................................... viii

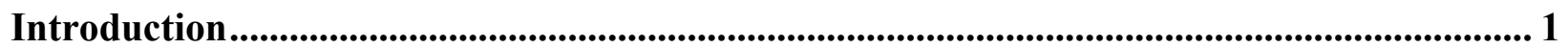

Hydrogen Production Potential............................................................................................................... 2

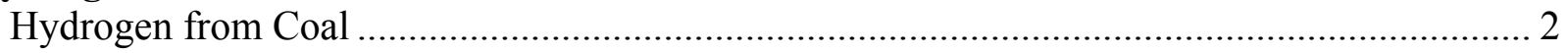

Hydrogen from Natural Gas......................................................................................... 4

Hydrogen from Nuclear and Hydro Power ......................................................................... 5

Hydrogen from All Resources ………………………...................................................... 9

Integrated Hydrogen Production Analysis........................................................................................ 11

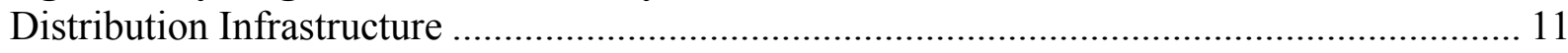

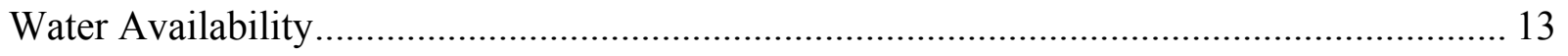

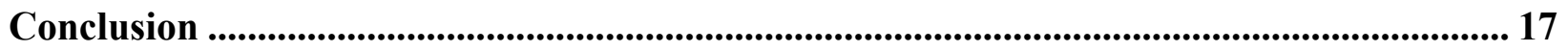

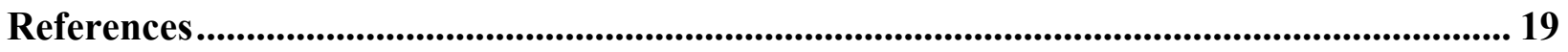




\section{List of Figures}

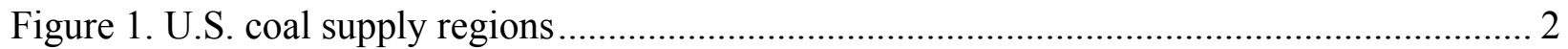

Figure 2. Hydrogen potential from coal resources by county ............................................. 3

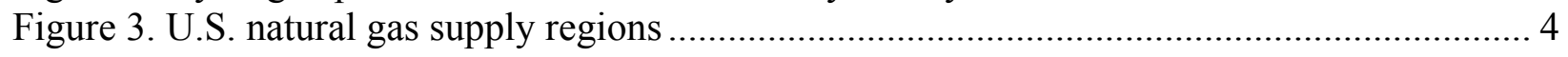

Figure 4. Hydrogen potential from natural gas by county ............................................... 5

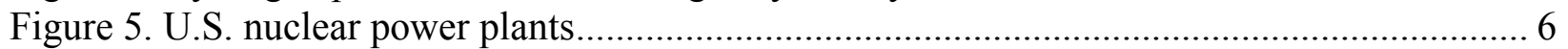

Figure 6. U.S. hydro power plants ............................................................................. 7

Figure 7. Hydrogen potential from nuclear power........................................................ 8

Figure 8 . Hydrogen potential from hydro power ........................................................ 8

Figure 9. Hydrogen potential from coal, natural gas, nuclear and hydro power as a percentage of

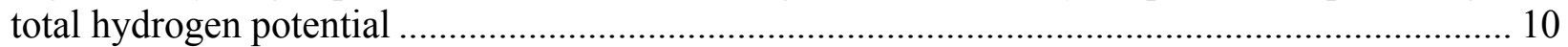

Figure 10. Hydrogen potential from coal, production facilities, and railroads.......................... 12

Figure 11. Hydrogen potential from natural gas, production facilities, and pipelines................ 12

Figure 12. Hydrogen potential from nuclear and hydro power, production facilities, and

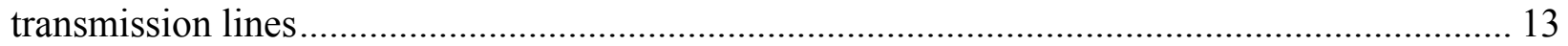

Figure 13. Average water needs for centralized hydrogen production by county, based on

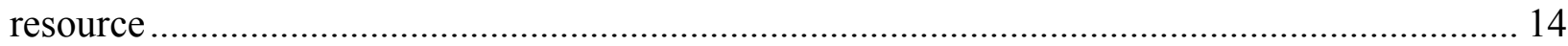

Figure 14. Water use by county, 2000 ........................................................................... 15

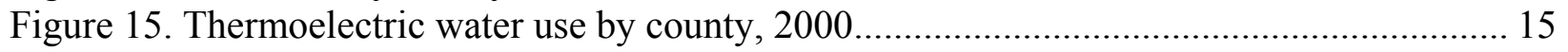

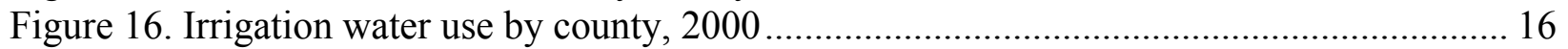

\section{List of Tables}

Table 1. U.S. Hydrogen Potential from Coal, Natural Gas, Nuclear, and Hydro Power (tonnes/year) 


\section{Introduction}

Today's energy supply system includes electricity, gasoline, natural gas, and diesel fuel, serving as energy carriers and produced by the conversion of energy sources such as coal, oil, natural gas, biomass, solar, wind, hydro, and nuclear power. Hydrogen is considered a potential energy carrier that could contribute to a more sustainable energy supply system because it can be produced from any primary energy source. There are roughly 8 million tonnes of hydrogen produced in the United States annually, used primarily for petroleum refining, and ammonia and methanol production. If used as a transportation fuel, this amount of hydrogen could power approximately 20-30 million cars (NHA 2008).

The objective of this study is to estimate the quantity of hydrogen that could be produced from coal, natural gas, nuclear, and hydro power by county in the United States, and to create maps for easy visualization of the results. To accomplish this, fossil fuel production and power generation data are analyzed both statistically and graphically using a state-of-the-art GIS, a computer-based information system used to create, manipulate, analyze, and visualize geographic information.

Nearly all of the hydrogen in the United States today is produced by steam reforming of natural gas, and this method of production is expected to dominate for the near term. Coal is by far the most abundant and available fossil fuel in the country and technologies for gasifying coal to produce hydrogen are in relatively advanced states of development. Another method to produce hydrogen is via electrolysis of water-splitting water with an electric current. Electrolysis offers great locational advantages for either distributed production at fueling stations or other points of use, or at electrical generation facilities as a way of using excess power generation at night or during other off-peak periods. For example, both nuclear power plants and, to a lesser extent, hydroelectric power plants operate as base-load facilities and therefore have the potential to supply electricity for hydrogen production during off-peak-demand periods.

One of the drawbacks of producing hydrogen from coal and natural gas is the production of carbon dioxide during the reforming process, meaning carbon capture will be an important operation for environmentally benign utilization of these resources in the future. Likewise, the environmental profile of hydrogen produced via electrolysis will depend on the feedstock and configuration of the power plant. Although renewable electrolysis is not cost effective today, it is considered a viable option for the future. 


\section{Hydrogen Production Potential}

\section{Hydrogen from Coal}

Hydrogen produced from coal is considered a promising near- to mid-term opportunity in the United States due to widely-available, inexpensive coal resources and existing gasification technologies.

Coal is by far our most abundant remaining fossil fuel resource. The United States has the world's largest proven reserves of coal—about 247 billion tonnes estimated at the end of 2006 (BP 2007). The United States produced about 1 billion tonnes in 2006 and annual production has been steady at about that amount in recent years. Figure 1 depicts the United States' coal supply regions. Leading states in coal production are Wyoming, West Virginia, and Kentucky. In addition to resource availability, coal is a relatively inexpensive resource. In 2006, on a dollarsper-million-Btu basis, natural gas was the most expensive fossil fuel (\$6.94), petroleum was second (\$6.23), and coal was least expensive (\$1.69) (EIA 2008).

Hydrogen and electricity can be co-produced from coal via gasification, followed by reforming of a portion of the produced gas, and combusting the remaining gas in a combined cycle. After hydrogen separation, carbon dioxide $\left(\mathrm{CO}_{2}\right)$ can be captured and sequestered if the coal plant is located close enough to a suitable sequestration site so that $\mathrm{CO}_{2}$ transport is not prohibitive.

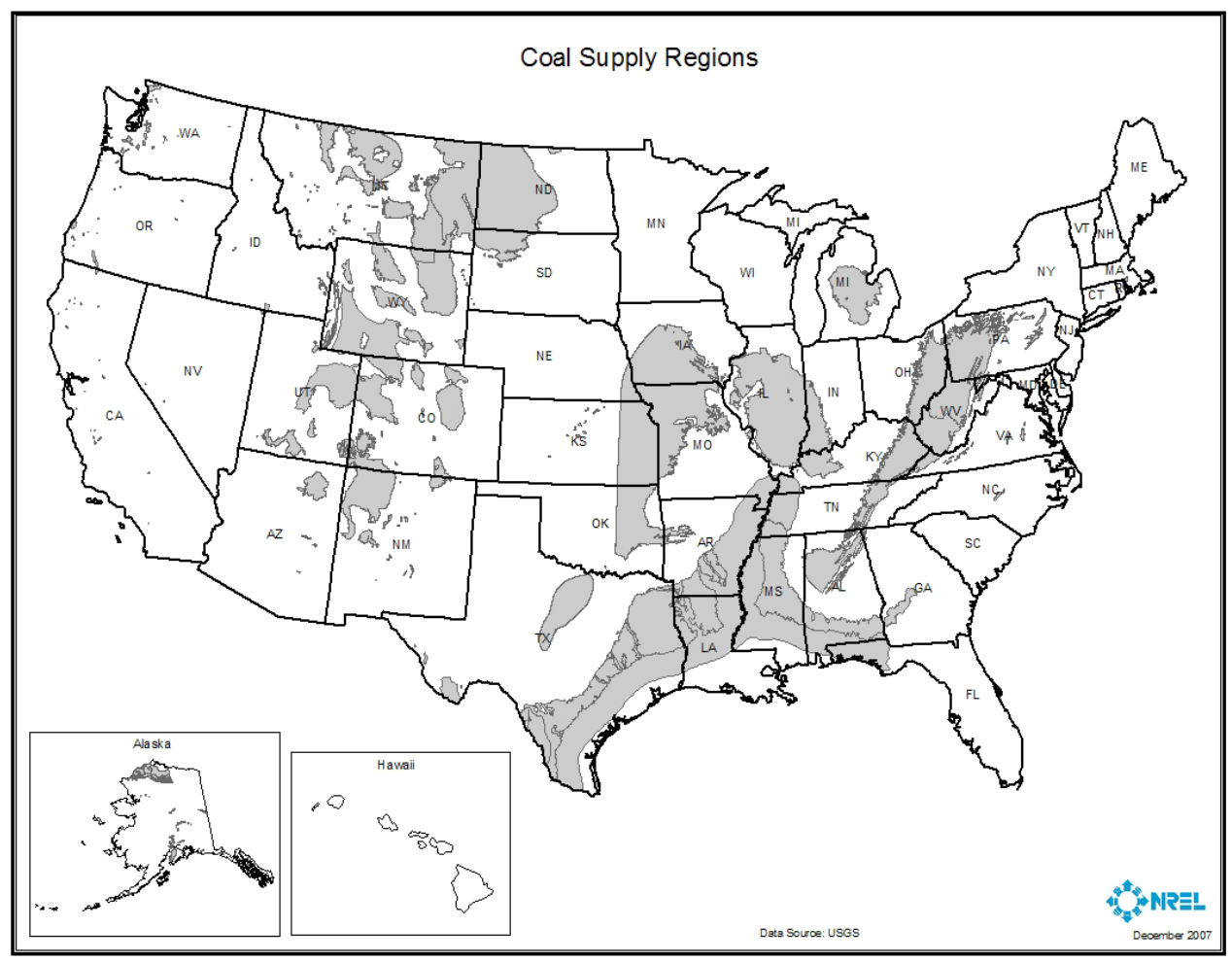

Figure 1. U.S. coal supply regions 
To estimate the hydrogen potential from coal, data on coal production in 2005 by county was obtained from the Energy Information Administration (EIA). It is unrealistic to assume that all of this production would be used for hydrogen; therefore, a conservative assumption of $30 \%$ was used in this study. A relationship formula of $7.6 \mathrm{~kg}$ of coal per $\mathrm{kg}$ of hydrogen was applied, based on the conversion of coal to hydrogen via gasification according to the U.S. Department of Energy's (DOE) Hydrogen Analysis (H2A) Group. ${ }^{2}$ Therefore, the amount of hydrogen that could potentially be produced from coal annually in the United States is about 40 million tonnes. This estimate assumes that coal production would keep steady as it has been during the recent years (about 1 billion tonnes annually) and that only 30\% of this resource is dedicated to hydrogen production. States with the highest potential are Wyoming, West Virginia, Kentucky, and Pennsylvania (see Table 1). It is important to note that not all areas with coal resources, illustrated in Figure 1, are currently producing. Figure 2 depicts the counties with coal mining activities in 2005 and their hydrogen potential. As this analysis includes only the currently producing counties, the map below does not mirror the coal supply regions map.

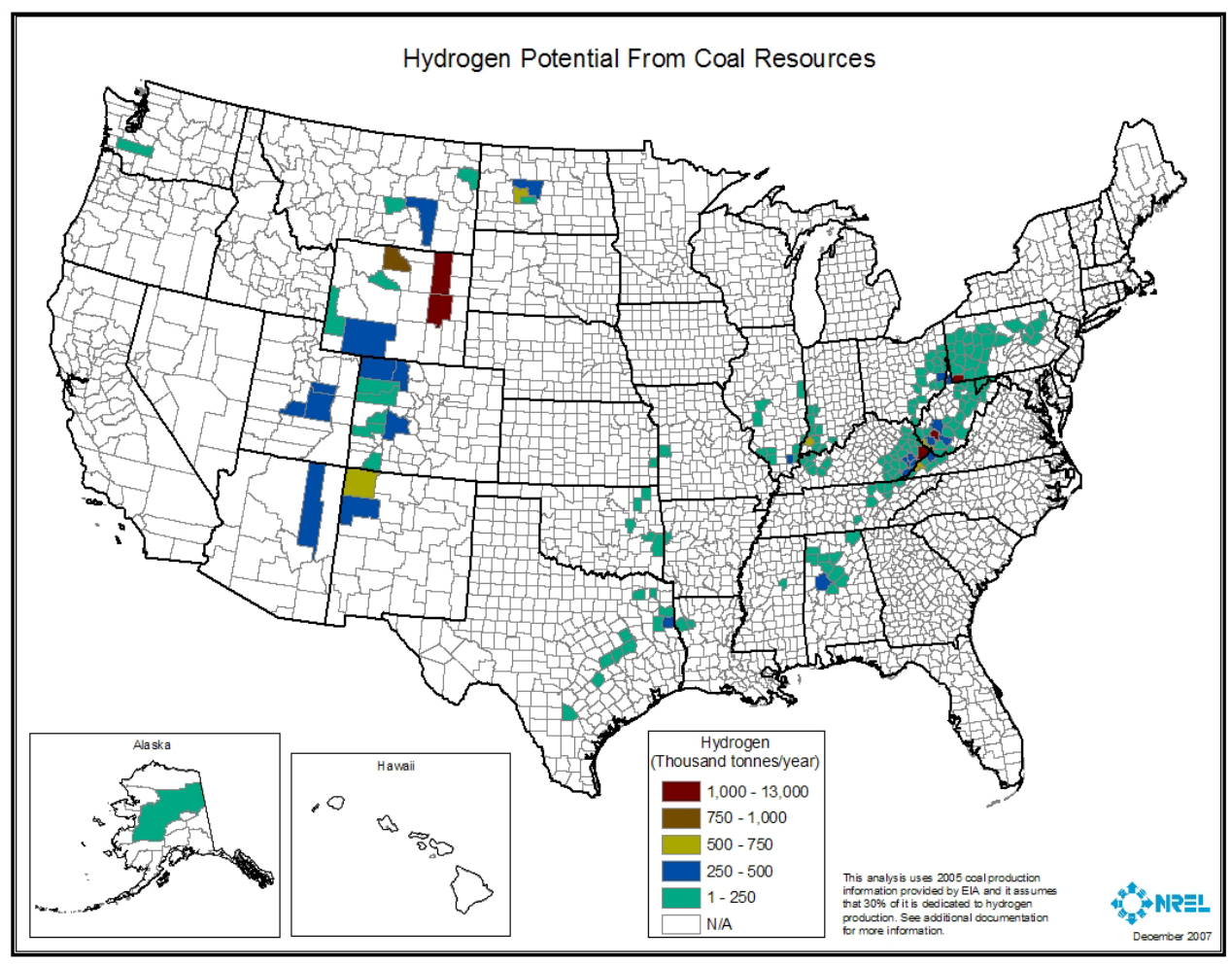

Figure 2. Hydrogen potential from coal resources by county

\footnotetext{
${ }^{2}$ Most of the hydrogen production assumptions used in this report are derived from the H2A model. The H2A model was developed to provide a consistent way to analyze and compare prospective hydrogen production and delivery technologies. It analyzes discounted cash-flow hydrogen production costs using a standard calculation methodology and clearly specified assumptions. The key attribute of $\mathrm{H} 2 \mathrm{~A}$ is that the methodology and assumptions all were developed with extensive input and acceptance from hydrogen stakeholders. $\mathrm{H} 2 \mathrm{~A}$ is available free on the Web at www.hydrogen.energy.gov/h2a analysis.html.
} 


\section{Hydrogen from Natural Gas}

Today, almost all hydrogen is produced from natural gas. Natural gas is a gaseous fossil fuel consisting mainly of methane $\left(\mathrm{CH}_{4}\right)$, some higher hydrocarbons, and $\mathrm{CO}_{2}$. Hydrogen is produced from natural gas via steam methane reforming (SMR) ${ }^{3}$, a widely used process in the industry today. Depending on the price of natural gas and electricity, carbon capture and sequestration constraints, and the availability of viable hydrogen transportation and storage technologies, steam reforming of natural gas may be the least expensive means of producing hydrogen. However, there are still some challenges facing the technology such as improved reforming efficiencies, more durable reforming catalysts, and reduced carbon sequestration costs.

The United States' natural gas withdrawals in 2006 were 23.5 trillion cubic feet and have been relatively steady at that amount in recent years. Proven reserves were estimated at about 209 trillion cubic feet at the end of 2006 (BP 2007). Figure 3 illustrates the location of natural gas supply regions. Demands on natural gas resources are expected to increase, indicating future use of natural gas for hydrogen production may compete with use for home heating, electrical generation, plastics and chemicals manufacture, and perhaps natural gas vehicles.

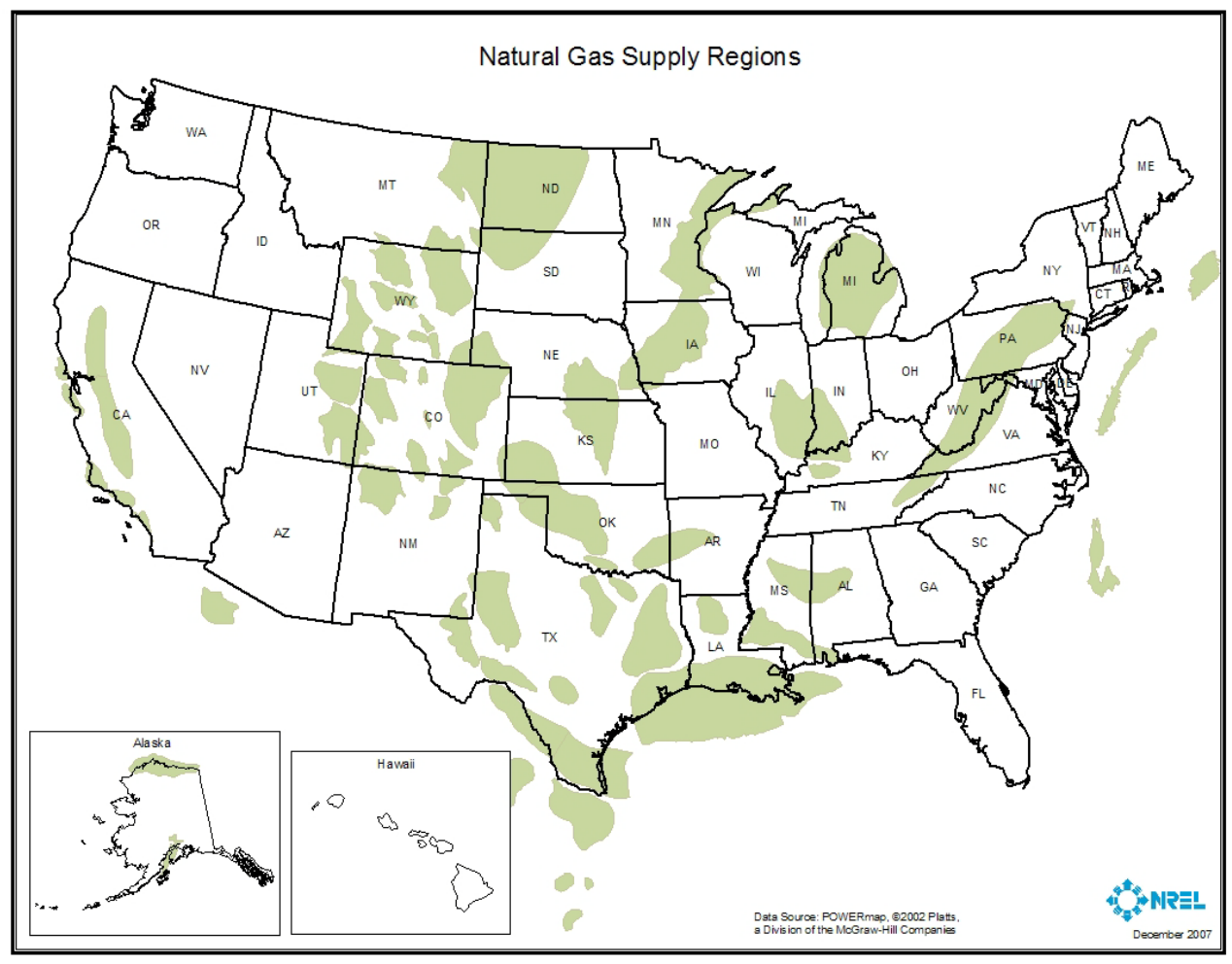

Figure 3. U.S. natural gas supply regions

\footnotetext{
${ }^{3}$ Steam reforming converts methane (and other hydrocarbons in natural gas) into hydrogen and carbon monoxide by reaction with steam over a nickel catalyst.
} 
The hydrogen potential from natural gas was estimated using data from the EIA on natural gas withdrawals by state in 2005. This information was disaggregated to county level using the location of gas wells. The number of wells within each county and their percentage of all wells within the state was calculated, and the state level information on natural gas withdrawals was distributed based on these percentages. A relationship formula of 4.5 normal cubic meters per $\mathrm{kg}$ of hydrogen was applied based on the conversion of natural gas to hydrogen via SMR according to the H2A Group. The amount of hydrogen that could potentially be produced from natural gas annually in the United States is estimated at about 27 million tonnes. This estimate assumes that natural gas production would keep steady as it has been during the recent years (about 23.5 trillion cubic feet annually) and, similarly to coal, only $30 \%$ of this production is used for hydrogen. States with the highest production potential are Texas, Wyoming, Oklahoma, and New Mexico (see Table 1). It is important to note that not all areas with natural gas resources, illustrated in Figure 3, are currently producing. Figure 4 depicts the counties with natural gas drilling activities in 2005 and their hydrogen potential. As this analysis includes only the currently producing counties, the map below does not mirror the natural gas supply regions map.

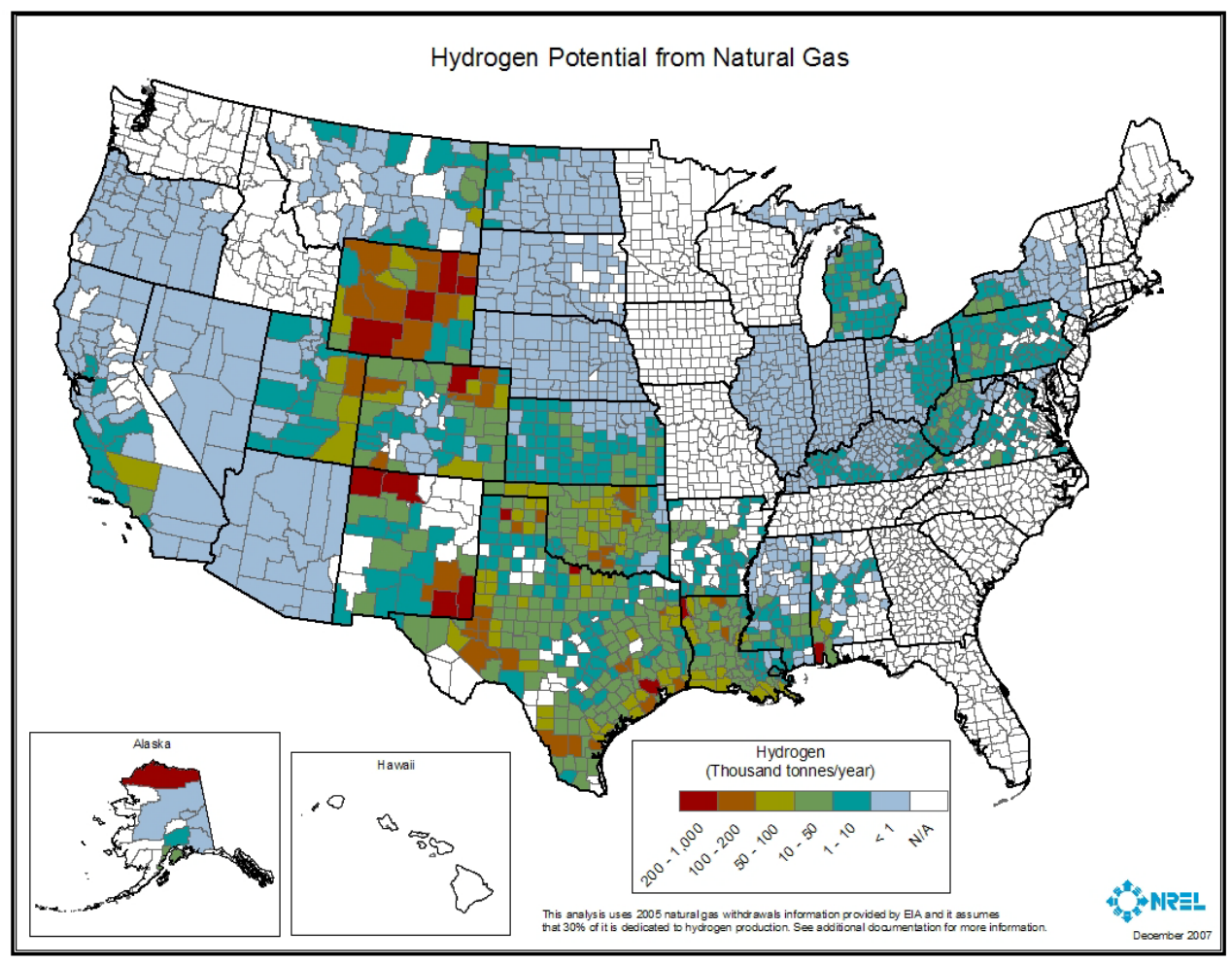

Figure 4. Hydrogen potential from natural gas by county

\section{Hydrogen from Nuclear and Hydro Power}

Nuclear power plants are a good source of base-load power generation and are generally operated at full capacity around the clock, regardless of power demand levels. As such, systems with large nuclear components may generate excess power at night or other low-demand periods. This power could be used for generating hydrogen via electrolysis. In 2006, U.S. electrical production from nuclear power was 784 million MWh from 66 power plants throughout the 
United States, primarily in the Northeast, South, and Midwest (see Figure 5). This production was lower than past levels due to the retirement of older nuclear reactors without the construction of a new reactor since 1996. While the timing of new U.S. nuclear power plant construction remains an open issue, potential new technologies being considered for the next generation nuclear power production are well suited for the thermo-chemical cycles under consideration for future hydrogen production. For example, high-temperature gas reactors and other potential next generation nuclear technologies operate at temperatures that are better suited for sulfur-iodine and other high-temperature thermo-chemical hydrogen production cycles (i.e., more than $700^{\circ} \mathrm{C}$ compared to about $350^{\circ} \mathrm{C}$ from current U.S. light-water-reactor technology). Although the thermo-chemical cycles under consideration have major technical and cost risks, they have the potential to be much more cost competitive than electrolysis-based hydrogen production options.

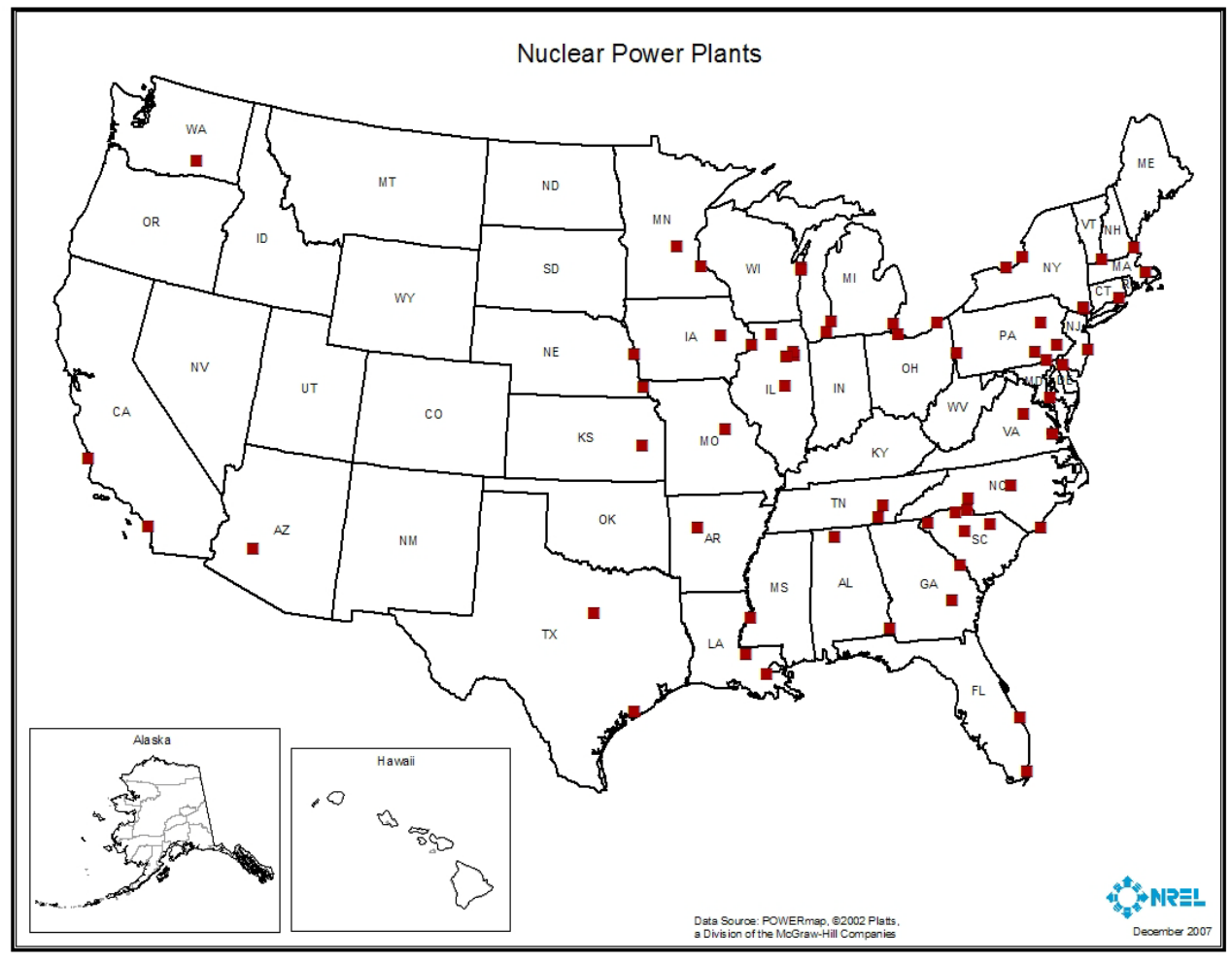

Figure 5. U.S. nuclear power plants

In 2006, U.S. hydropower production was 216 million MWh from 1,321 plants throughout the United States. (see Figure 6). Hydropower accounts for more than $75 \%$ of the electricity generated from renewable sources. Production varies more as a function of precipitation levels than addition or subtraction of power plants. Therefore, low rainfall and drought can affect significantly hydropower's reliability. DOE had set a goal to increase the generation at existing plants and harness undeveloped hydropower capacity without constructing new dams. This would be achieved by developing new, more advanced technologies that will improve the environmental performance and achieve greater energy efficiencies. 
Hydroelectric generators can be operated to match electrical demand to some extent, but meeting minimum downstream flow requirements and a variety of constraints limit this capability. During periods of low electrical demand, excess generation capacity can be used to pump water into a higher reservoir, which can be released back into a lower reservoir through a turbine during periods of high demand. This pumped storage approach improves the daily load factor of the generation system. However, the pumped storage approach has some inefficiencies associated with it, and some hydroelectric plants have no reservoir capacity (i.e., "run-of-theriver" plants). As such, there is potential for using excess generation for hydrogen production via electrolysis.

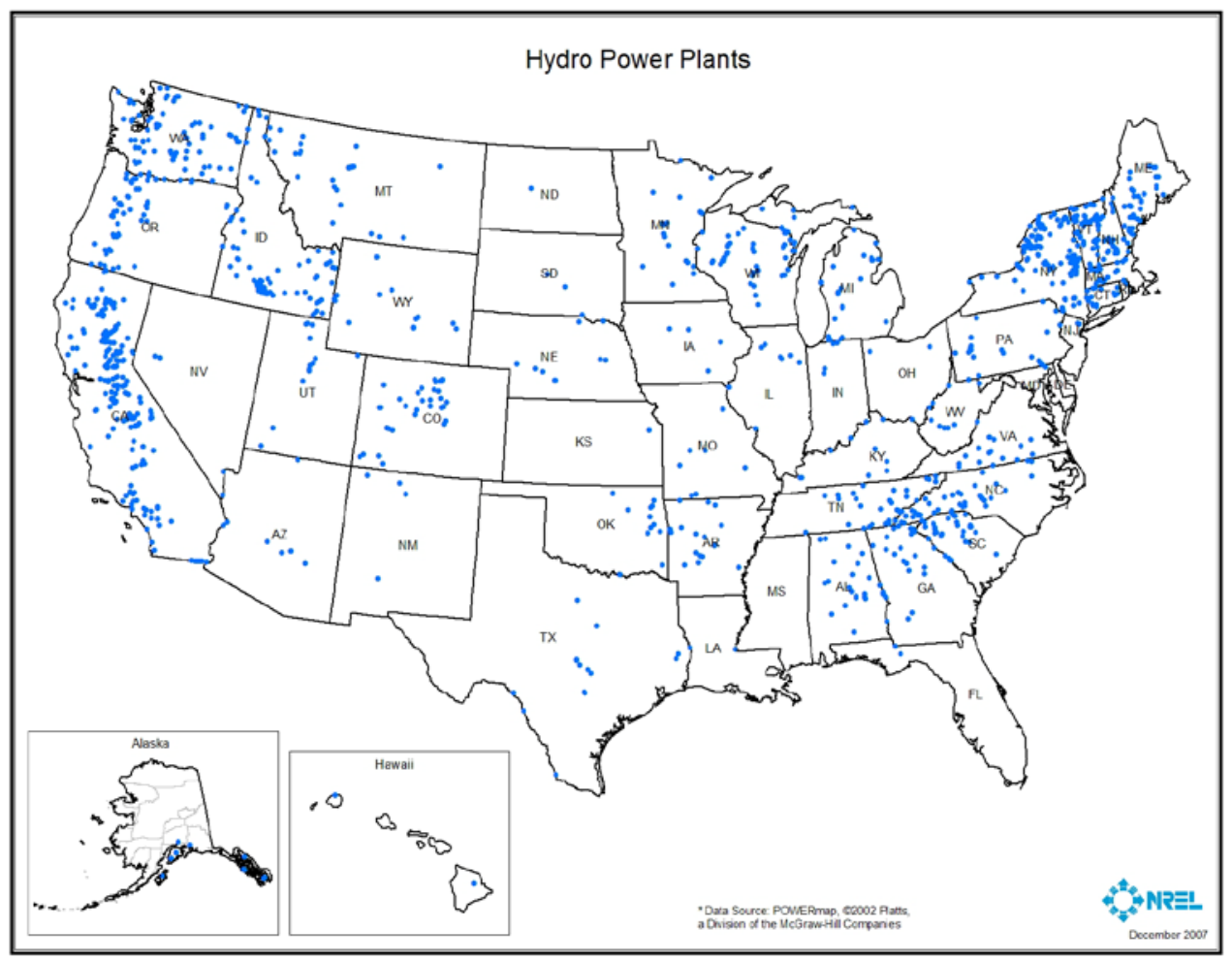

Figure 6. U.S. hydro power plants

Data on power generation by nuclear and hydro plants in 2006 was provided by Platts, a division of The McGraw-Hill Companies. This information was aggregated to county level and similarly to hydrogen from the coal and natural gas analysis; therefore, it was assumed that $30 \%$ of the power generation is dedicated to hydrogen production. A relationship formula of $58.8 \mathrm{kWh}$ per $\mathrm{kg}$ of hydrogen was applied, based on hydrogen production from nuclear and hydro power via electrolysis according to the H2A Group. The hydrogen potential from nuclear and hydro power annually in the United States is estimated at about 4 million tonnes and 1 million tonnes, respectively. This estimate takes into account electricity generation in 2006 and considers only $30 \%$ of this generation for hydrogen production. Table 1 illustrates the results of this analysis by state. States with the highest hydrogen potential from nuclear power include Illinois, Pennsylvania, and South Carolina, while Washington and California have the highest hydrogen potential from hydro power. The geographic distribution of this potential by county is shown in 
Figure 7 and Figure 8. Note that this analysis is based on existing installed capacity and does not include the potential for new generators.

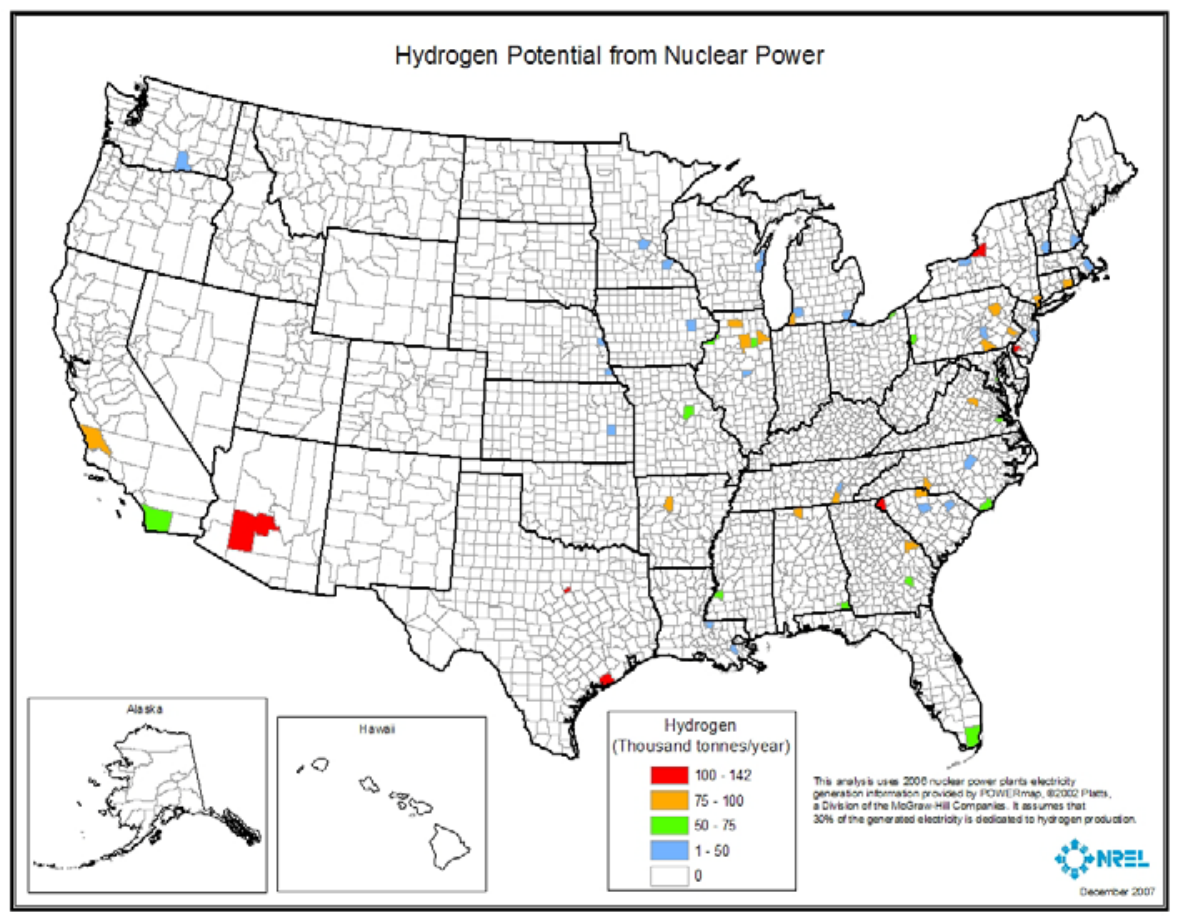

Figure 7. Hydrogen potential from nuclear power

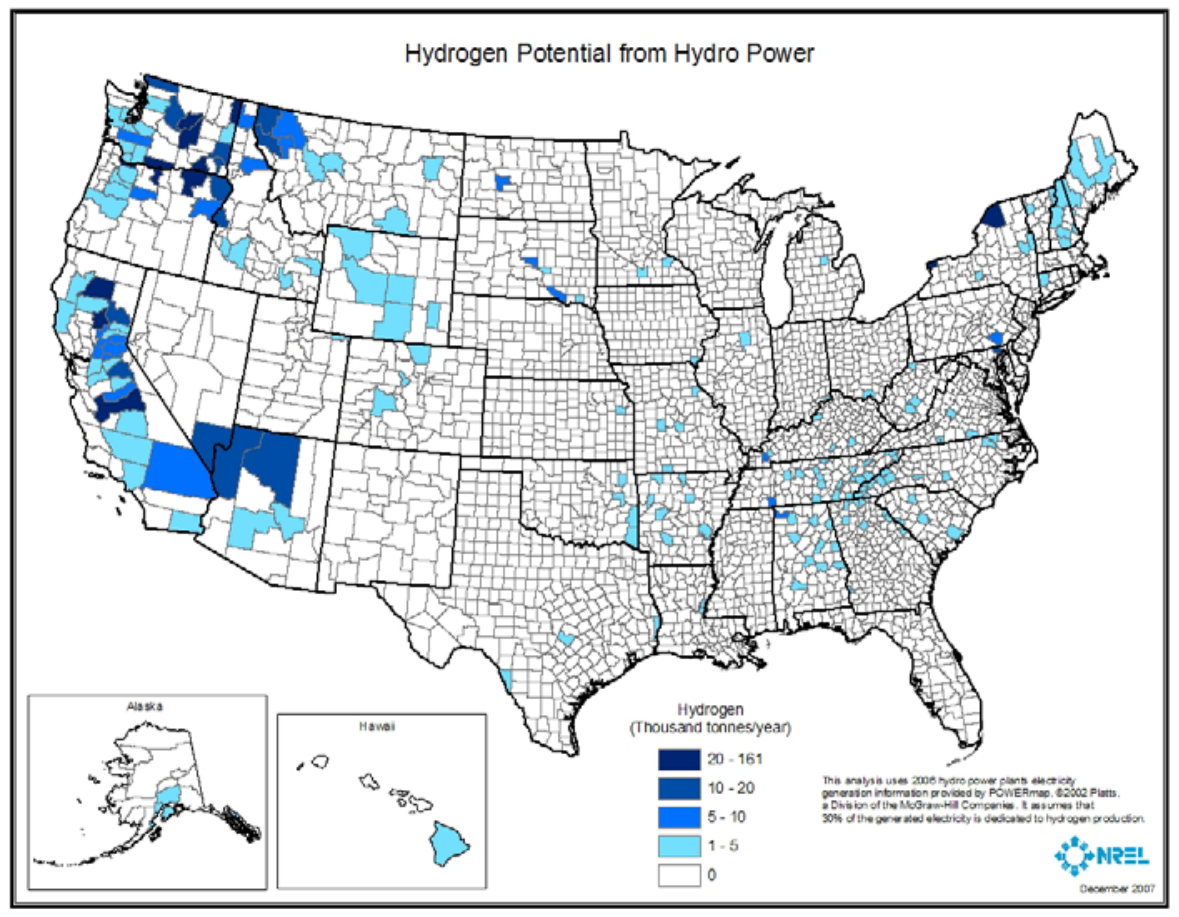

Figure 8. Hydrogen potential from hydro power 


\section{Hydrogen from All Resources}

Table 1. U.S. Hydrogen Potential from Coal, Natural Gas, Nuclear, and Hydro Power (tonnes/year)

\begin{tabular}{|c|c|c|c|c|}
\hline State & $\begin{array}{l}\text { Hydrogen from } \\
\text { Hydro Power }\end{array}$ & $\begin{array}{l}\text { Hydrogen from } \\
\text { Nuclear Power }\end{array}$ & $\begin{array}{l}\text { Hydrogen } \\
\text { from Coal }\end{array}$ & $\begin{array}{c}\text { Hydrogen } \\
\text { from Natural } \\
\text { Gas }\end{array}$ \\
\hline Alabama & 32,726 & 162,812 & 763,957 & 556,519 \\
\hline Alaska & 3,668 & 0 & 52,057 & 370,096 \\
\hline Arizona & 34,268 & 122,511 & 432,209 & 416 \\
\hline Arkansas & 5,219 & 77,717 & 107 & 323,421 \\
\hline California & 204,930 & 163,054 & 0 & 156,518 \\
\hline Colorado & 6,199 & 0 & $1,378,759$ & $1,851,974$ \\
\hline Connecticut & 98 & 84,640 & 0 & 0 \\
\hline Delaware & 0 & 0 & 0 & 0 \\
\hline District of Columbia & 0 & 0 & 0 & 0 \\
\hline Florida & 0 & 68,160 & 0 & 0 \\
\hline Georgia & 9,827 & 163,295 & 0 & 0 \\
\hline Hawaii & 177 & 0 & 0 & 0 \\
\hline Idaho & 40,489 & 0 & 0 & 0 \\
\hline Illinois & 109 & 480,378 & $1,146,221$ & 288 \\
\hline Indiana & 1,972 & 0 & $1,233,615$ & 5,601 \\
\hline lowa & 4,495 & 25,997 & 0 & 0 \\
\hline Kansas & 49 & 47,705 & 6,122 & 594,770 \\
\hline Kentucky & 12,983 & 0 & $4,286,828$ & 165,801 \\
\hline Louisiana & 3,639 & 85,385 & 148,975 & $2,165,540$ \\
\hline Maine & 9,104 & 0 & 0 & 0 \\
\hline Maryland & 10,644 & 70,563 & 185,565 & 82 \\
\hline Massachusetts & 0 & 29,743 & 0 & 0 \\
\hline Michigan & 109 & 148,299 & 0 & 381,266 \\
\hline Minnesota & 84 & 67,262 & 0 & 0 \\
\hline Mississippi & 0 & 53,156 & 127,278 & 329,462 \\
\hline Missouri & 1,146 & 51,616 & 21,410 & 0 \\
\hline Montana & 45,068 & 0 & 496,547 & 164,072 \\
\hline Nebraska & 0 & 45,932 & 0 & 1,685 \\
\hline Nevada & 10,306 & 0 & 0 & 9 \\
\hline New Hampshire & 5,830 & 47,948 & 0 & 0 \\
\hline New Jersey & 0 & 166,167 & 0 & 0 \\
\hline New Mexico & 0 & 0 & $1,021,055$ & $2,515,645$ \\
\hline New York & 105,740 & 215,428 & 0 & 98,001 \\
\hline North Carolina & 14,177 & 203,894 & 0 & 0 \\
\hline North Dakota & 7,760 & 0 & $1,072,504$ & 25,997 \\
\hline Ohio & 1,711 & 85,954 & 885,041 & 139,037 \\
\hline Oklahoma & 1,211 & 0 & 66,450 & $2,898,033$ \\
\hline Oregon & 141,301 & 0 & 0 & 811 \\
\hline Pennsylvania & 9,774 & 384,172 & $2,416,427$ & 301,071 \\
\hline Rhode Island & 0 & 0 & 0 & 0 \\
\hline South Carolina & 3,388 & 265,253 & 0 & 0 \\
\hline South Dakota & 20,337 & 0 & 0 & 797 \\
\hline Tennessee & 36,337 & 125,912 & 115,141 & 0 \\
\hline Texas & 1,022 & 210,532 & $1,644,737$ & $9,492,567$ \\
\hline Utah & 1,675 & 0 & 877,916 & 499,093 \\
\hline Vermont & 299 & 26,054 & 0 & 0 \\
\hline Virginia & 1,805 & 140,801 & 993,272 & 158,325 \\
\hline Washington & 436,169 & 47,593 & 188,537 & 0 \\
\hline West Virginia & 5,102 & 0 & $5,501,110$ & 387,529 \\
\hline Wisconsin & 0 & 62,416 & 0 & 0 \\
\hline Wyoming & 3,998 & 0 & $15,423,917$ & $3,221,271$ \\
\hline Total & $1,234,945$ & $3,930,351$ & $40,485,759$ & $26,805,697$ \\
\hline
\end{tabular}


Hydrogen Potential by State

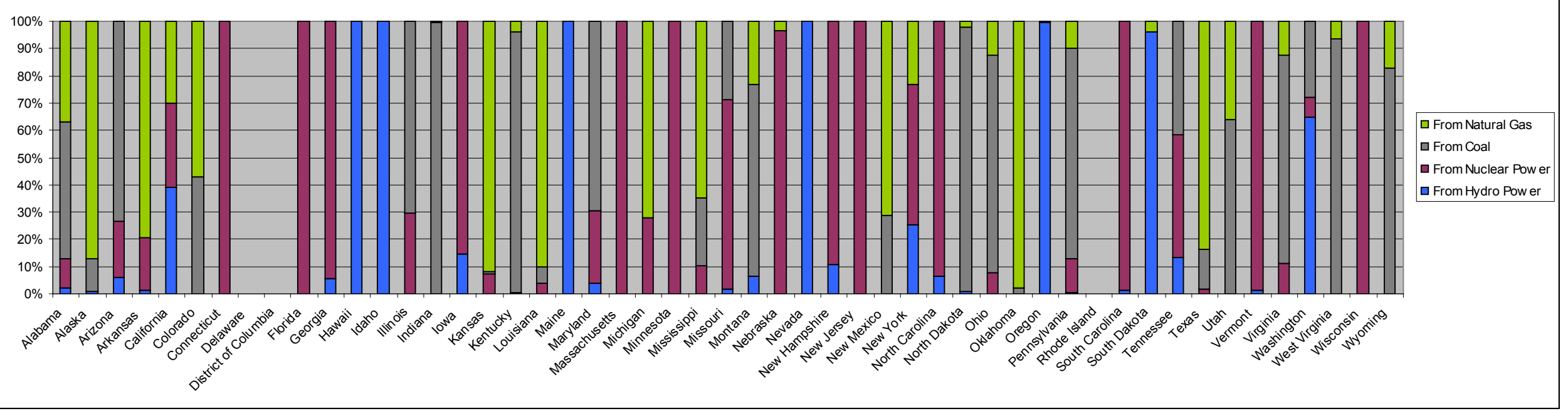

Figure 9. Hydrogen potential from coal, natural gas, nuclear and hydro power as a percentage of total hydrogen potential 


\section{Integrated Hydrogen Production Analysis}

Resource availability, as identified in the preceding analyses, is not the only factor to consider in assessing the likely locations for hydrogen production. Other factors include distribution infrastructure and water availability.

\section{Distribution Infrastructure}

Figures 10-12 illustrate the hydrogen potential by county and the relevant resource infrastructure - railroads for coal, pipelines for natural gas, and transmission lines for nuclear and hydroelectric power plants. Railroads might carry coal to hydrogen production facilities, or they could carry liquefied hydrogen made at any hydrogen production facility to market areas (i.e., points of end-use). Pipeline infrastructure might be used for shipping natural gas to a hydrogen production facility, or gaseous hydrogen product to market, or carbon dioxide to an appropriate sequestration site. Close proximity to transmission lines ensures electricity supply for hydrogen production via electrolysis. Additionally, the locations of existing hydrogen production facilities are shown on these maps as a reference.

Each map identifies counties with a minimum of 20,000 tonnes of hydrogen production potential per year. This number is derived from the H2A Group analysis, which identified the minimum economically viable hydrogen production level of a centralized facility to be $50,000 \mathrm{~kg}$ per day, or approximately 20,000 tonnes per year. Combining this information with existing infrastructure gives a good pictorial, if not quantitative, suggestion as to where hydrogen production from the various resources might develop.

Figure 10 illustrates that the Rocky Mountain States, because of their large resource base and distance from demand centers, are good candidates for siting large centralized hydrogen production facilities using coal resources. Large scale plants can be built as far as several hundred miles from the point of end-use. Other states with good hydrogen potential from coal such as West Virginia, Pennsylvania, and Kentucky may be better suited for semi-central production plants, or 25 to 100 miles from the point of end-use. The Rocky Mountain States (in addition to Texas, Louisiana, and Oklahoma) are also suitable for large-scale hydrogen production from natural gas due to availability of both resources and pipeline infrastructure (see Figure 11). Locations with good hydrogen potential from nuclear and hydro resources are relatively close to demand centers and therefore may be better suited for semi-central production facilities (see Figure 12). 


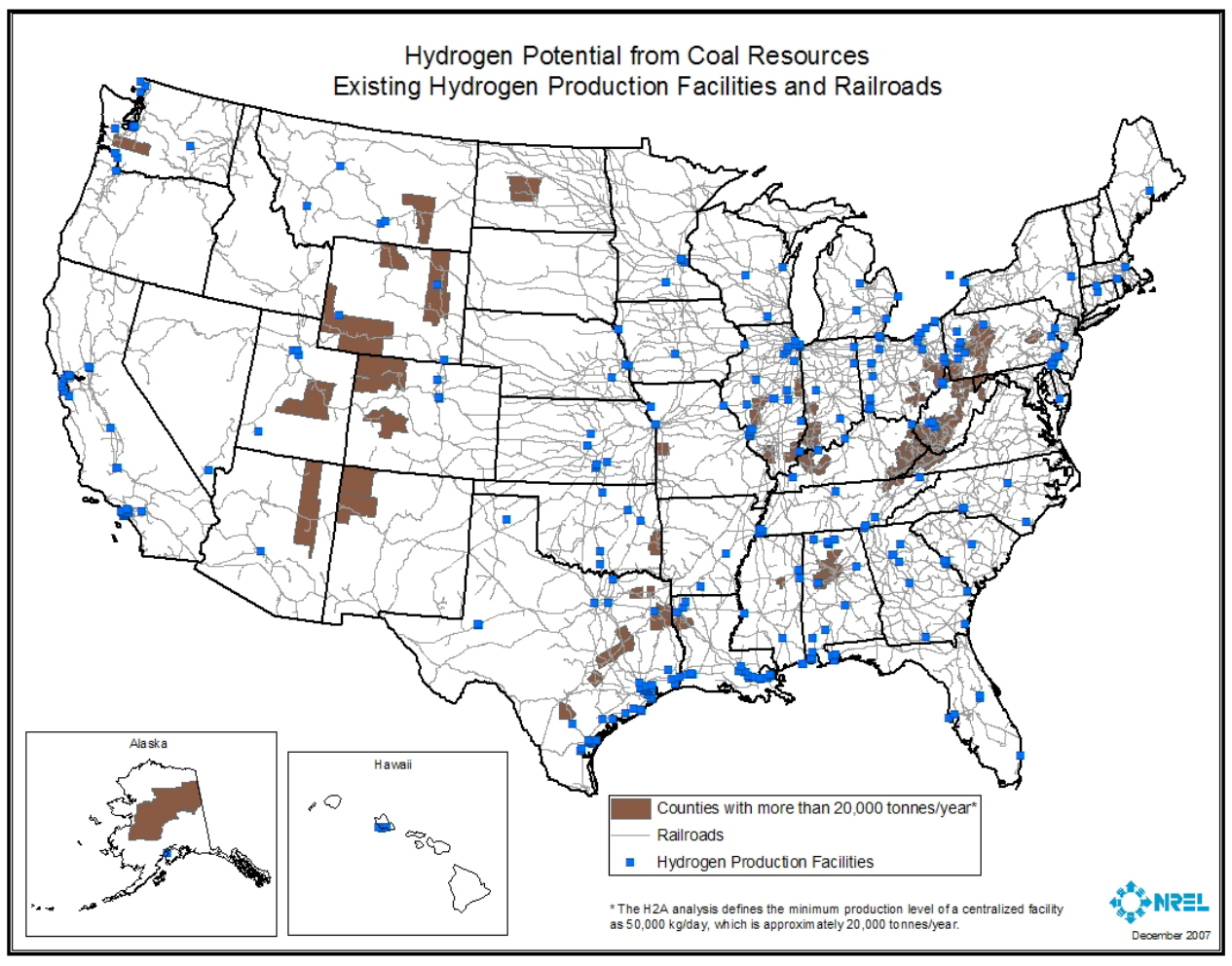

Figure 10. Hydrogen potential from coal, production facilities, and railroads

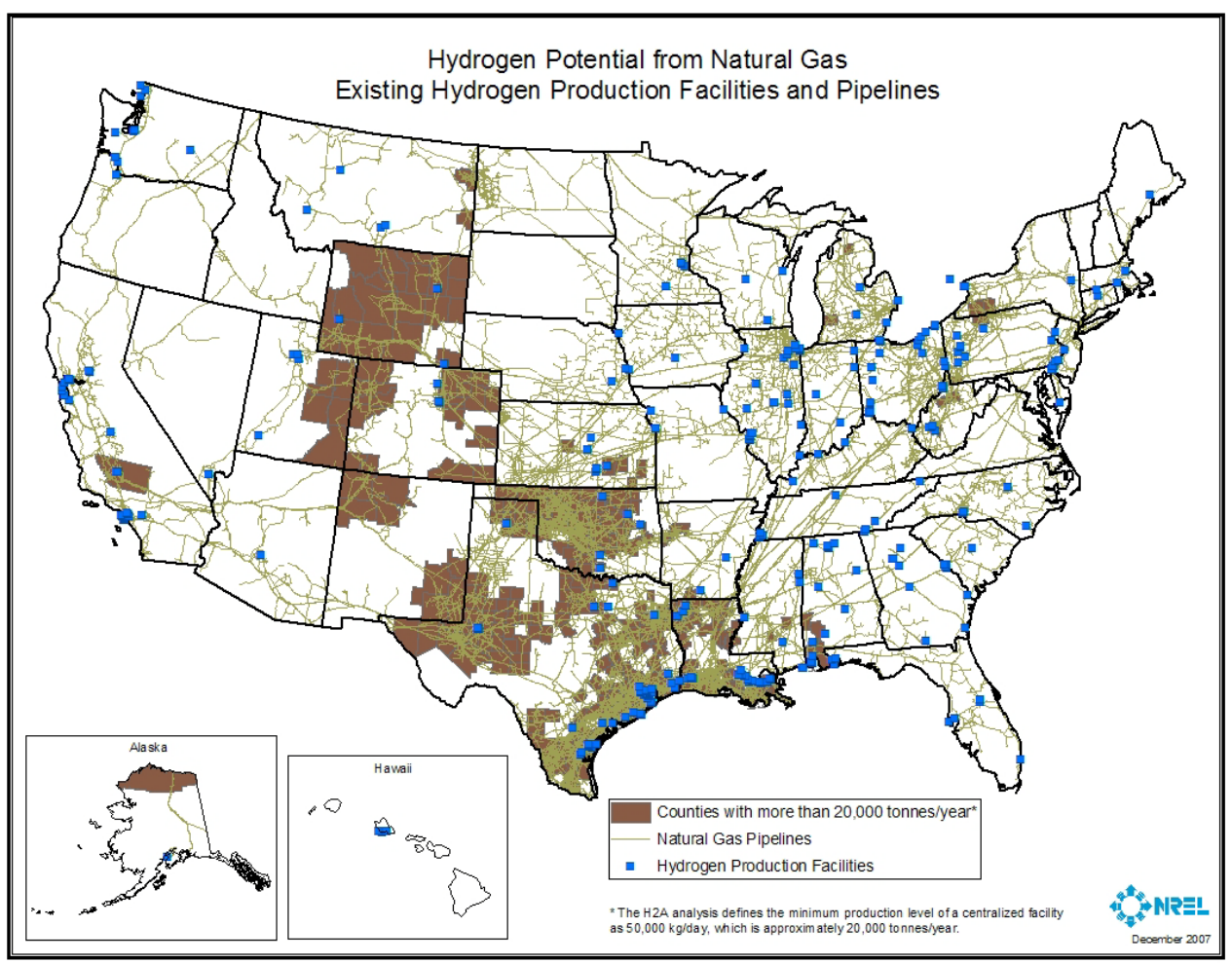

Figure 11. Hydrogen potential from natural gas, production facilities, and pipelines 


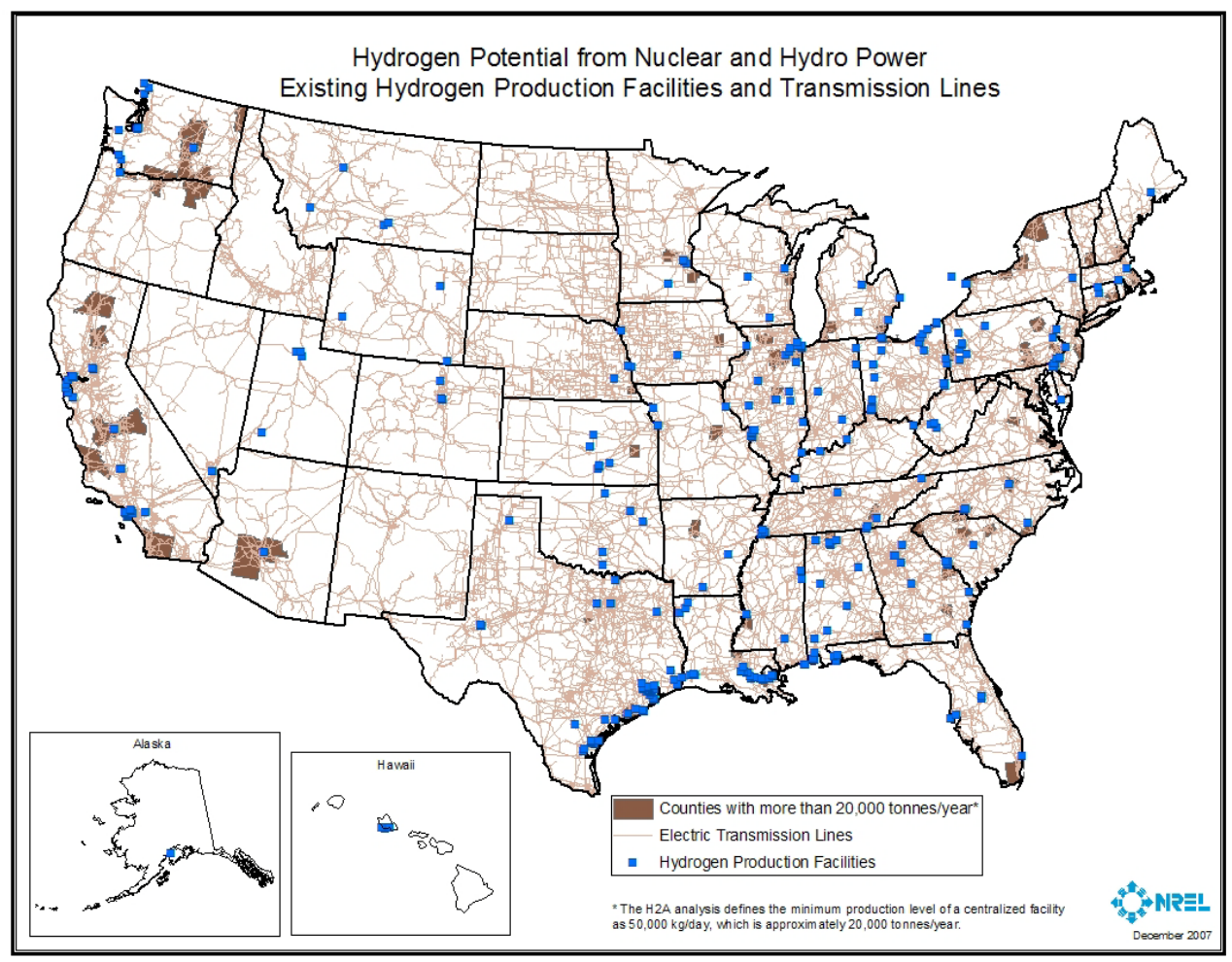

Figure 12. Hydrogen potential from nuclear and hydro power, production facilities, and transmission lines

\section{Water Availability}

When choosing a site for a hydrogen production facility it is important to understand the approximate water needs for hydrogen production, as well as water supply and demand in a given area. The quantity of water needed for hydrogen production varies by feedstock, conversion process, and size of the facility. The results of an analysis of the average water needs for centralized hydrogen production facilities are presented in Figure 13. The authors assume that on average three gallons of water are needed to produce one kilogram of hydrogen, an average relationship derived from the H2A Group. The analysis is built on the analytical results presented in Figures 10-12, considering only those counties that meet the minimum production requirement for a centralized plant, or at least 20,000 tonnes of hydrogen production potential per year.

Water supply analysis was not possible for this study due to lack of water availability data. A comprehensive water resource assessment has not been conducted since 1978, when the U.S. Water Resources Council published the National Water Assessment. State and local governments have done water availability studies for their respective geographic areas, but they need to be integrated and supplemented to form a single reference product that provides nationwide coverage. The U.S. Geological Survey (USGS) has undertaken this effort and results will be available in late 2009 or early 2010. 


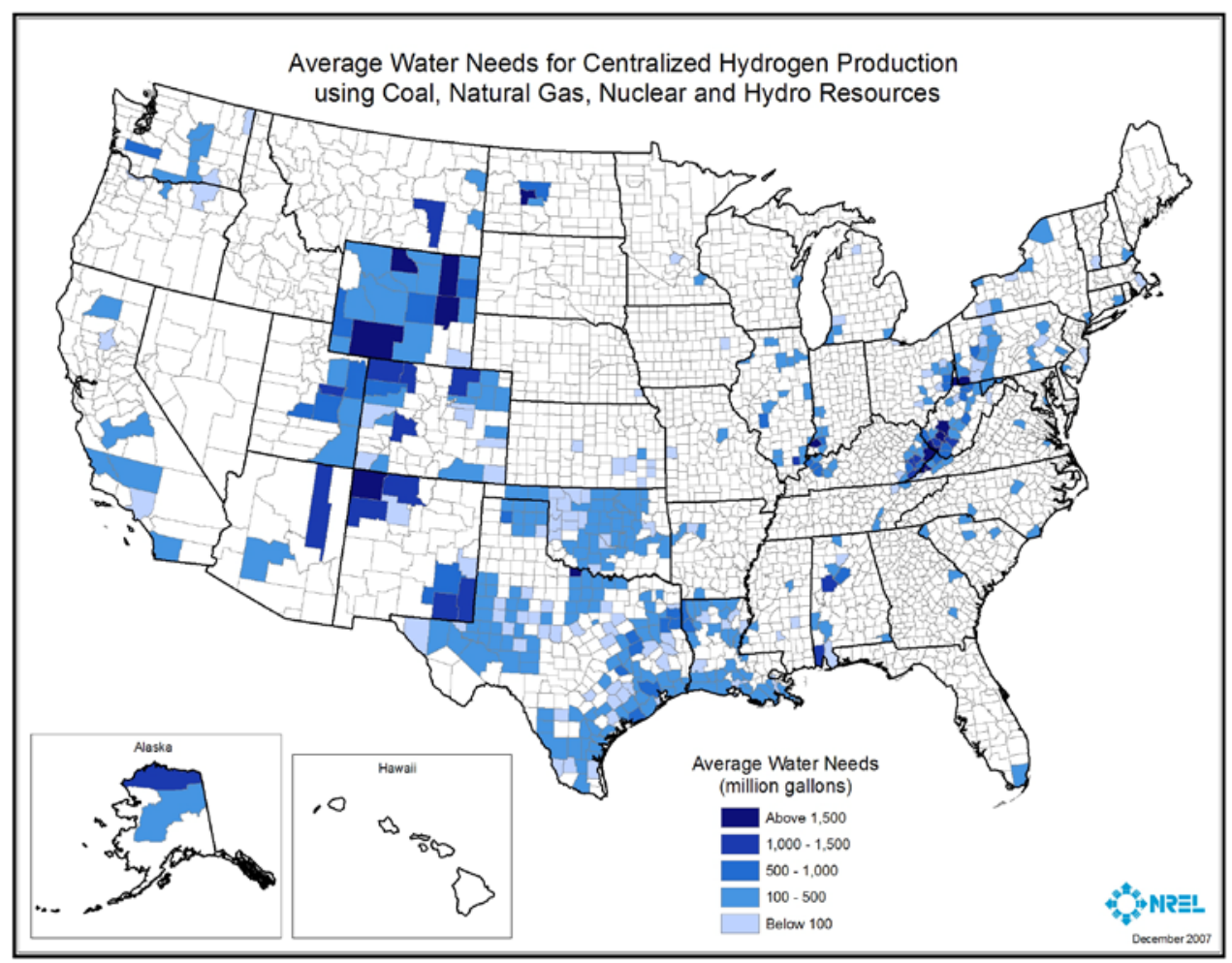

Figure 13. Average water needs for centralized hydrogen production by county, based on resource

Water demand analysis was also difficult due to lack of up-to-date data. The most recent information on water use is from $2000^{4}$. The categories with the largest water withdrawals in 2000 were thermoelectric power (48\% of total withdrawals) and irrigation ( $34 \%$ of the total withdrawals). The remaining $18 \%$ of withdrawals are shared by public supply, self-supplied industrial, self-supplied domestic, livestock, aquaculture, and mining. Figure 14 illustrates the total water use by county in 2000, and Figures 15 and 16 show the water consumption by the two main users: thermoelectric and irrigation sectors.

Based on a simple analysis of the available information, it appears that counties in the Rocky Mountain States may experience difficulties with the availability of water for hydrogen production due to an increasing supply shortage and competition from other sectors, particularly crop irrigation. These areas have an average annual precipitation of less than 20 inches, which is insufficient to support crops without supplemental water. USGS points out that the majority of withdrawals for irrigation (86\%) and irrigated acres $(75 \%)$ were in the 17 conterminous Western States, as illustrated in Figure 16. A more precise analysis on water supply and demand is necessary to determine the water constraints for hydrogen production in the United States.

\footnotetext{
${ }^{4}$ The USGS will release 2005 data in the summer of 2009.
} 


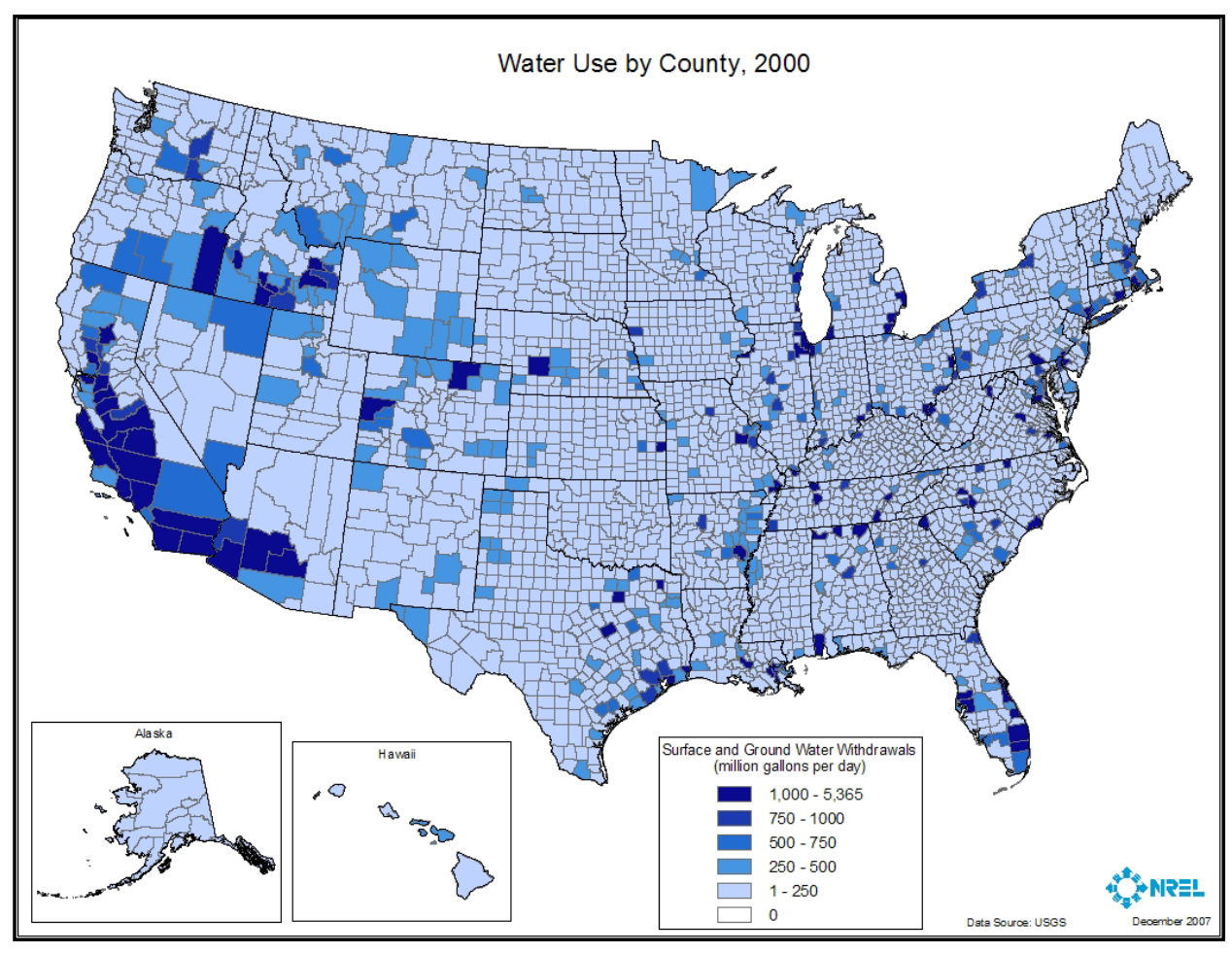

Figure 14. Water use by county, 2000

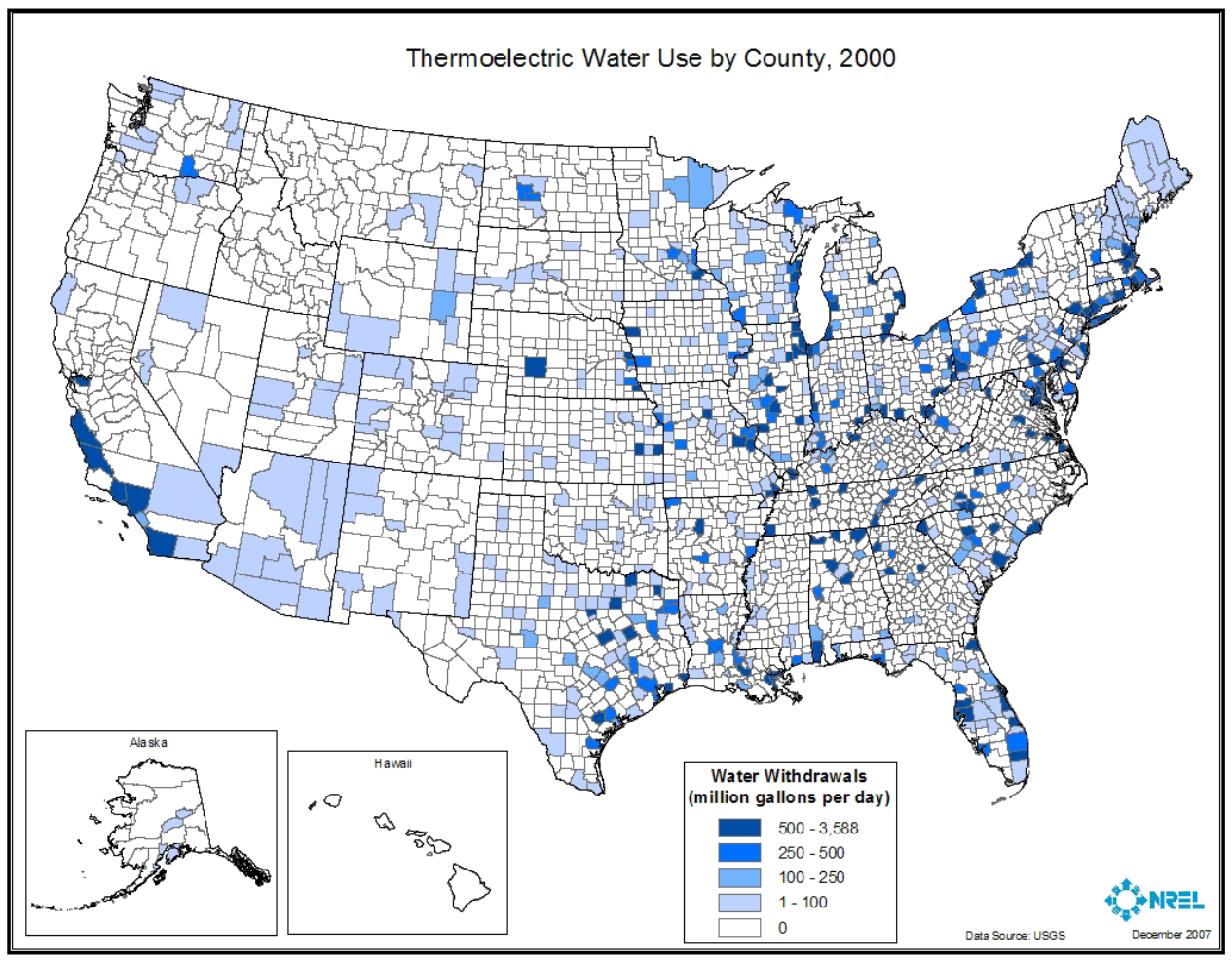

Figure 15. Thermoelectric water use by county, 2000 


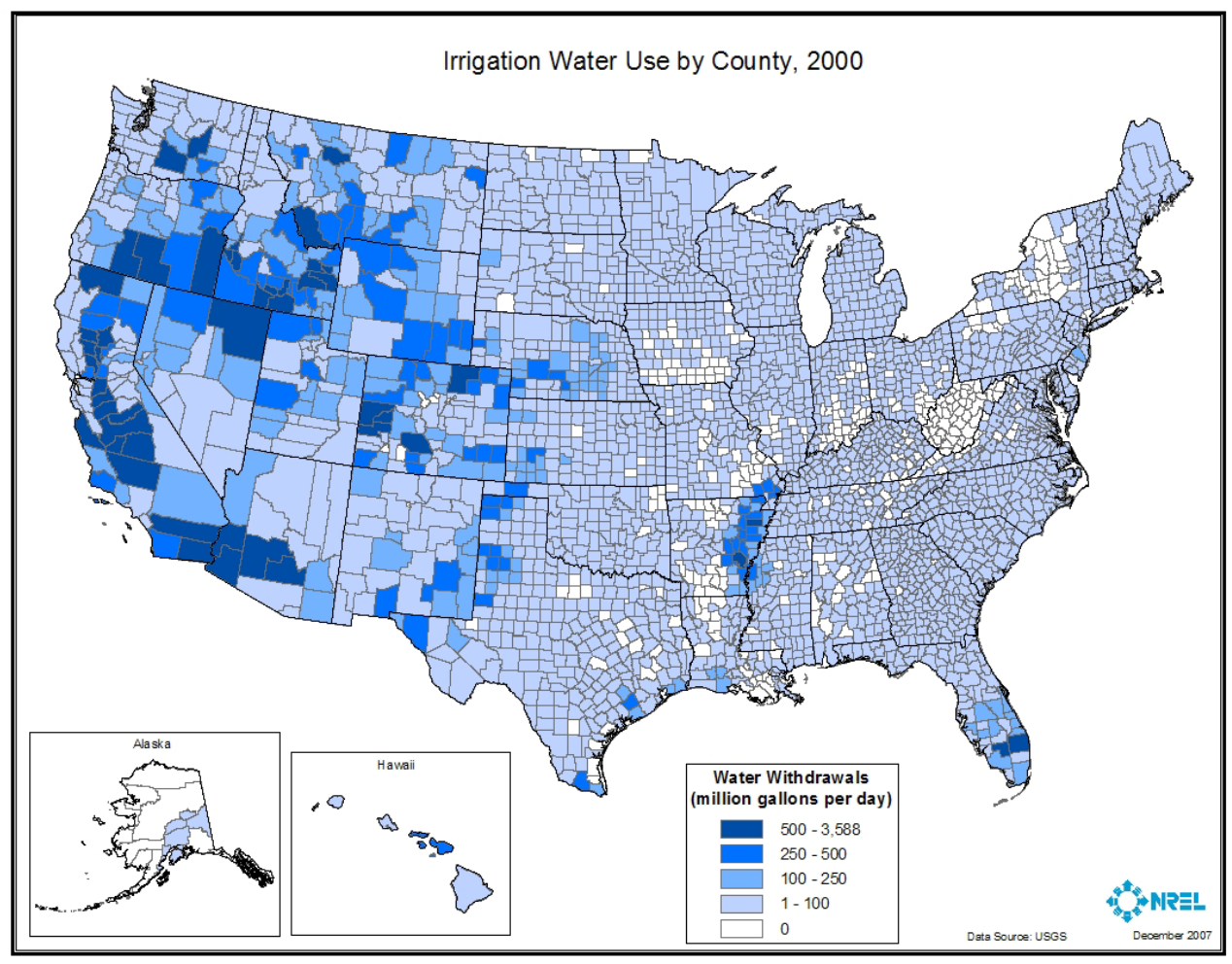

Figure 16. Irrigation water use by county, 2000 


\section{Conclusion}

As an energy carrier, hydrogen can be produced from any primary energy source. Currently, most hydrogen is produced from natural gas via SMR. Other sources like coal and biomass can also be used to generate hydrogen through gasification. Electricity, once produced from nuclear, hydro, solar, wind, or geothermal, can generate hydrogen through electrolysis. Given that this wide diversity of energy resources is geographically specific, it's important to understand where resources are located so that appropriate plans can be made for production technologies and infrastructure. This study used a GIS framework to analyze the spatial distribution of natural gas and coal resources, as well as hydro and nuclear power generation, and evaluate their potential for hydrogen production. It estimated that more than 72 million tonnes of hydrogen can be produced from these sources per year (considering only $30 \%$ of their total current annual production). Leading states include Wyoming (26\% of total potential), Texas (16\%), West Virginia (8\%), Kentucky (6\%), and New Mexico (5\%). The United States consumed about 396 million tonnes of gasoline in 2007 (IEA 2008); therefore, the amount of hydrogen derived from these sources could displace about $80 \%$ of this consumption. Although the ultimate goal of a hydrogen-driven economy is based on renewable and low-carbon resources, using fossil resources as a bridge can help the build-out of renewable energy and hydrogen delivery infrastructures.

In addition to estimating the hydrogen potential from the sources mentioned above, the study discussed the major factors that need to be considered when choosing a site for a hydrogen production facility. These include the availability of feedstock, distribution infrastructure, and water. The study concluded that regions with high hydrogen potential, such as the Rocky Mountain States, have access to existing distribution infrastructure, but they may experience some difficulties with water availability. Meaningful water supply and demand analyses were not possible due to lack of recent data. Water analyses are needed to determine the water constraints for hydrogen production in the United States, and as an input to a comprehensive hydrogen infrastructure analysis.

Previous work by the authors (Milbrandt and Mann 2007) estimated the hydrogen production potential from key renewable resources (wind, solar, and biomass) in the United States at about 1,000 million tonnes per year. This potential is significantly higher than that estimated in the present study because wind and solar resources (the major contributors) are exceptionally significant and available everywhere, while the resources considered in this study are exhaustible and location-specific. Additionally, the previous study estimated the maximum hydrogen potential from renewable resources, while this study estimated the hydrogen potential from current fossil fuels and electricity (nuclear and hydro) production. The authors considered the current production of coal and natural gas instead of reserves, because the reserves' quantity may not be feasible due to technological, economic, or environmental difficulties associated with the extraction process, and the fact that the annual production of these resources has been steady over the recent years. The same applies to electricity production from nuclear and hydro plants, which have been consistent in recent years. Although this study uses current production of coal/natural gas and electricity generation from nuclear/hydro power plants rather than the total 
amount of resources available or power generation capacity, it helps highlight opportunities for first-generation hydrogen production during the transition period to a clean hydrogen economy. 


\section{References}

1. Argonne National Laboratory (February 2004). Basic Research Needs for the Hydrogen Economy. Chicago, IL: Argonne National Laboratory. http://www.sc.doe.gov/bes/reports/files/NHE_rpt.pdf

2. British Petroleum (BP) (June 2007). "Statistical Review of World Energy." http://www.bp.com/liveassets/bp internet/globalbp/globalbp uk english/reports and pu blications/statistical_energy_review_2007/STAGING/local assets/downloads/spreadshee ts/statistical review full report workbook 2007.xls

3. Djomo, S.; Humbert, S.; Blumberga, D. (June 2008). "Life cycle assessment of hydrogen produced from potato steam peels." International Journal of Hydrogen Energy (33:12); pp. 3067-3072.

4. Energy Information Administration (EIA) (2008a). "Summary Statistics for the United States - Cost of Fuel at Electricity Generators." Energy Information Administration online. Accessed May 2008. http://tonto.eia.doe.gov/dnav/ng/ng prod sum dcu NUS a.htm

5. Energy Information Administration (EIA) (2008b). "Petroleum Basic Statistics for 2007." Energy Information Administration online. Accessed April 2008. http://www.eia.doe.gov/basics/quickoil.html

6. Energy Information Administration (EIA) (2008c). "Natural Gas Gross Withdrawals and Production." Energy Information Administration online. Accessed March 2008.

7. Energy Information Administration (EIA) (2008d). "U.S. Coal Production." Accessed March 2008. http://www.eia.doe.gov/cneaf/coal/page/acr/table1.html

8. Energy Information Administration (EIA) (2007). "International Energy Outlook 2007." Energy Information Administration online. Accessed May 2008. http://tonto.eia.doe.gov/ftproot/forecasting/0484(2007).pdf

9. Milbrandt. A.; Mann, M. (February 2007). Potential for Hydrogen Production from Key Renewable Resources in the United States. NREL/TP-640-41134. Golden CO: National Renewable Energy Laboratory. http://www.nrel.gov/docs/fy07osti/41134.pdf

10. National Hydrogen Association. "Hydrogen's Properties.” National Hydrogen Association online. Accessed March 2008. http://www.hydrogenassociation.org/general/basics.asp

11. Platts, a division of The McGraw-Hill Companies. Licensed GIS data on power generation by nuclear and hydro plants in the United States in 2006. http://www.platts.com/

12. U.S. Department of Energy (DOE). "DOE H2A Analysis.” U.S. Department of Energy Hydrogen Program online. Accessed March 2008.

13. U.S. Department of Energy (DOE) (July 2004). "Hydropower - Setting a Course for Our Energy Future." http://www.nrel.gov/docs/fy04osti/34916.pdf

14. U.S. Geological Survey (USGS) (May 2006). National Coal Resources Database. Accessed February 2008. http://energy.er.usgs.gov/products/databases/USCoal/

15. U.S. Geological Survey (USGS) (March 2004). "Estimated Use of Water in the United States in 2000.” USGS online. Accessed March 2008. http://water.usgs.gov/watuse/ 
16. U.S. Geological Survey (USGS) (2002). "Concepts for National Assessment of Water Availability and Use.” Report to Congress, Circular 1223, Reston Virginia.

http://pubs.usgs.gov/circ/circ1223/pdf/C1223.pdf 


\section{REPORT DOCUMENTATION PAGE}

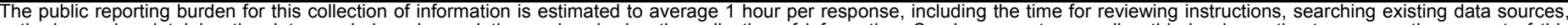

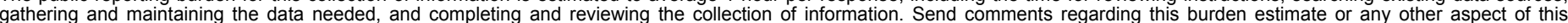

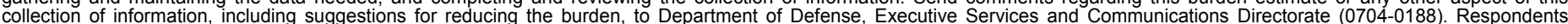

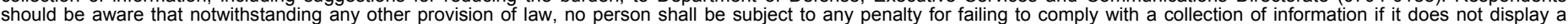

should be aware that notwithstanding

PLEASE DO NOT RETURN YOUR FORM TO THE ABOVE ORGANIZATION.

\section{REPORT DATE (DD-MM-YYYY) \\ February 2009}

\section{TITLE AND SUBTITLE}

Hydrogen Resource Assessment: Hydrogen Potential from Coal, Natural Gas, Nuclear, and Hydro Power
3. DATES COVERED (From - To)

5a. CONTRACT NUMBER

DE-AC36-08-GO28308

5b. GRANT NUMBER

5c. PROGRAM ELEMENT NUMBER

5d. PROJECT NUMBER

NREL/TP-6A2-42773

5e. TASK NUMBER

$\mathrm{H} 278.2100$

5f. WORK UNIT NUMBER
7. PERFORMING ORGANIZATION NAME(S) AND ADDRESS(ES)

National Renewable Energy Laboratory

1617 Cole Blvd.

Golden, CO 80401-3393

9. SPONSORING/MONITORING AGENCY NAME(S) AND ADDRESS(ES)

\section{PERFORMING ORGANIZATION REPORT NUMBER}

NREL/TP-6A2-42773
10. SPONSOR/MONITOR'S ACRONYM(S) NREL

11. SPONSORING/MONITORING AGENCY REPORT NUMBER

12. DISTRIBUTION AVAILABILITY STATEMENT

National Technical Information Service

U.S. Department of Commerce

5285 Port Royal Road

Springfield, VA 22161

13. SUPPLEMENTARY NOTES

14. ABSTRACT (Maximum 200 Words)

This paper estimates the quantity of hydrogen that could be produced from coal, natural gas, nuclear, and hydro power by county in the United States. The study estimates that more than 72 million tonnes of hydrogen can be produced from coal, natural gas, nuclear, and hydro power per year in the country (considering only $30 \%$ of their total annual production). The United States consumed about 396 million tonnes of gasoline in 2007; therefore, the report suggests the amount of hydrogen from these sources could displace about $80 \%$ of this consumption.

15. SUBJECT TERMS

Hydrogen production potential; technologies; infrastructure; United States; NREL; Milbrandt; Mann.

\begin{tabular}{|c|c|c|}
\hline $\begin{array}{l}\text { a. REPORT } \\
\text { Unclassified }\end{array}$ & $\begin{array}{l}\text { b. ABSTRACT } \\
\text { Unclassified }\end{array}$ & $\begin{array}{l}\text { c. THIS PAGE } \\
\text { Unclassified }\end{array}$ \\
\hline
\end{tabular}

\begin{tabular}{l|l|} 
17. & LIMITATION \\
OF ABSTRACT & $\begin{array}{l}\text { 18. } \\
\text { NUMBER } \\
\text { OF PAGES } \\
\text { UL }\end{array}$ \\
\end{tabular}

19a. NAME OF RESPONSIBLE PERSON

19b. TELEPHONE NUMBER (Include area code) 